of the 477 carriers present should be detected-that is, 271 . Thus $100,000 \mathrm{Vi}$ titres would have saved 95,523 stool cultures as compared with screening the whole group by stool culture, though 513 carriers would have been detected by the later method ( $57 \%$ of 900$)$.

A similar exercise in Britain would result in 100,000 Vi titres saving 98,829 stools, with a $40 \%$ chance of detecting the one expected carrier. (Calculated from figures in the P.H.L.S.W.P., 1961).

To put it in another way which takes no account of the number of carriers who are missed, the group with positive Vi titres contains in Hong Kong 477 carriers in 4,477 people, or a carrier rate of more than 1 in 10 , as compared with a carrier rate of 1 in 111 in the general population. In Britain the Vi-positive group has a carrier rate of 1 in 1,171 , as compared with 1 in 100,000 in the general population.

For screening special groups in which a missed carrier would constitute a serious risk to the community it would seem appropriate to concentrate first on the positive $\mathrm{Vi}$ reactors and then to carry out stool and urine culture on the negative Vi reactors. If the ideal of three stool and urine cultures-expected to detect $72 \%$ of carriers (P.H.L.S.W.P., 1961) - is not practicable at least one culture of each kind would offer a good prospect of detecting the most dangerous type of carrier in whom excretion is practically continuous. For larger groups the Vi test is the only practical screening test available.

The assessment of the value and limitations of the Vi test in different circumstances calls for judgement based on consideration of all the factors involved, theoretical and local.

In general it can be said that the $\mathrm{Vi}$ test is less reliable as a screening test in Hong Kong than in Britain, though the increased incidence of carriers in Hong Kong results in a greater number being detected. Other countries for which figures are available appear to come somewhere between these two extremes. We consider that our findings confirm the need to make a fresh assessment of the value of the Vi test for each area.

\section{Summary and Conclusions}

The upper limit of normal for the Vi titre in Hong Kong has been assessed at 32. Four per cent. of the population showed titres above this level. These figures are higher than have been recorded elsewhere.

In a series of 75 proved cases of typhoid the Vi reaction was found to be of no value either in the diagnosis of the acute attack or in the forecasting of clinical relapses.

The carrier rate in the adult population of Hong Kong has been estimated to be in the region of 9 per thousand ( 1 in 111).

The $\mathrm{Vi}$ test makes it possible to suspect $53 \%$ of the carriers in Hong Kong. However, the presence of $4 \%$ false positives adds considerably to the amount of work required to confirm the carrier state.

We wish to thank Dr. P. H. Teng, Director of Medical and Health Services, Hong Kong, for permission to publish this paper (though the views expressed therein are not necessarily those of the Medical and Health Department), and to the Government Pathelogist and staff of the Pathological Institute, Hong Kong, for advice and technical assistance. It is with pleasure that we record our appreciation of Mr. Michael Ip, head clerk at Lai Chi Kok Hospital. who not only cheerfully accepted the extra burden of clerical work but also acted as interpreter. We owe a similar debt of gratitude to Miss A. Cheng, health visitor, Kowloon, whose dedicated enthusiasm made the follow-up possible.

\section{REFERENCES}

Bhatnagar, S. S. (1938). Brit. med. 7., 2, 1195.

Bokkenheuser, V., and Richardson, N. (1964). Amer. F. publ. Hlth, 54

Eliot, C. P. (1940). Amer. F. Hyg., 31, Sect. B., p. 8.

Felix, A. (1938). Lancet, $\mathbf{2}, 738$

Forgan, E. S., and Drysdale, A. (1940). Ibid., 1, 1084.

Longfellow, D., and Luippold, G. F. (1943). Amer. F. Hyg., 37, 206.

Luippold, G. F. (1944). Science, 99, 497.

McFadzean, A. J. S., and Ong, G. B. (1966). Brit. med. F., 1, 1567.

Public Health Laboratory Service Working Party (1961). F. Hyg. (Lond.), $59,231$.

Toussaint, J. (1966). Med. 7. Aust., 1, 340.

Wilson, G. S. (1928). F. Hyg. (Lond.), 28, 295

\title{
The Thymus in Systemic Lupus Erythematosus: a Quantitative Histopathological Analysis and Comparison with Stress Involution*
}

\author{
GIDEON GOLDSTEIN, $† \S \|$ M.D., M.R.A.C.P. ; IAN R. MACKAY, $\$ \S$ M.D., M.R.C.P., F.R.A.C.P.
}

Brit. med.9., 1967, 2, 475-478

The recent demonstration that the thymus is concerned with the function of the immune system has stimulated interest in thymic pathology. Burnet (1962) found germinal centres and "lymphocyte proliferation" in the thymic medulla of NZB mice with autoimmune haemolytic anaemia; he speculated that " the forbidden clones concerned with systemic lupus erythematosus arise in the thymus and that in an early untreated case the thymus would be found to be enlarged and to contain numerous lymphoid follicles."

Mackay, Masel, and Burnet (1964) and Burnet and Mackay (1965) reported two cases of systemic lupus erythematosus with abnormalities in the thymic medulla, these being aggregates of epithelial cells and numerous plasma cells in one case and * Publication No. 1063 from the Walter and Eliza Hall Institute of Medical Research, Melbourne.

tPathologist to the Clinical Research Unit of the Walter and Eliza Hall Institute of Medical Research, Melbourne, and the Royal Melbourne Hospital.

¥ Head of the Clinical Research Unit of the Walter and Eliza Hall Institute of Medical Research, Melbourne, and the Royal Melbourne $\checkmark$ Working with the aid of a grant from the National Health and Medical Research Council of Australia.

II Presen: address: Laboratory of Immunology, National Institute of Allergy and Infectious Diseases, National Institute of Health, Bethesda, Maryland, U.S.A. typical germinal centres in the other, and Hutchins and Harvey (1964) described 13 cases in which the medulla contained epithelial aggregates and numerous plasma cells. Goldstein and Mackay (1965) made a quantitative study of the thymus in systemic lupus erythematosus ; the significant changes included cortical atrophy, epithelial cell aggregates in the medulla, cystic Hassall's corpuscles, and numerous plasma cells. However, we could not be sure of the specificity of these changes, since the histological appearance of the thymus changes greatly with age and stress (Hammar, 1921). We therefore analysed quantitatively the thymic changes in 198 control cases grouped according to age and the expected degree of stress involution. With this basis for comparison we found that the thymus in systemic lupus erythematosus showed the combined features of extreme involution and of immunological reaction within the medulla.

\section{Cases Studied and Controls}

The thymus was obtained from 13 patients with classical clinical and serological features of systemic lupus erythematosus. All the patients were females aged from 15 to 56 years; there were three surgical specimens (Mackay and Smalley, 1966) and 
10 necropsy specimens. Control specimens obtained from 198 patients of both sexes aged from 0 to 85 years were placed into two groups. The first group comprised 94 specimens, including 16 biopsies at thoracotomy and 78 necropsy specimens from patients with a terminal illness less than 24 hours; the second group comprised 104 thymuses from patients with a terminal illness of more than one week. These two groups were thought to exemplify " minimal stress" and "stress involution" (Boyd, 1932). The diagnosis in 198 controls included cerebrovascular accident, myocardial infarction, congenital heart disease, chronic rheumatic heart disease, leukaemia, lymphoma, cancer, pyelonephritis, pneumonia, trauma, poisoning, and drowning. Cases with autoimmune disease or with an unknown or doubtful diagnosis were excluded.

\section{Definitions}

"Epithelial cell aggregates" consisted of compact masses of cells thought to be derived from thymic reticuloepithelial cells. These cells were usually spindle-shaped, but were occasionally polyhedral and had an indistinct cell membrane and a large oval nucleus with stippled chromatin. The aggregates were sparsely infiltrated with lymphocytes and often contained extracellular structureless eosinophilic material.

Hassall's corpuscles were of (a) epithelial type, consisting of whorls of epithelial cells often lacking a defined central cavity, and $(b)$ cystic type lined by flattened epithelial cells often surrounded by epithelial cell aggregates.

Germinal centres were required to have a rim of lymphocytes and a central area of large cells with copious cytoplasm and pale nuclei, some mitotic figures, and macrophages with ingested nuclear debris.

\section{Quantitative Analysis}

A quantitative analysis was made of thymic components by the method described by Goldstein and Mackay (1965) and Goldstein (1967). A circle of 64 sq. mm. was drawn over the section and the thymus within this circle was projected on to paper. The area occupied by cortex, medulla, and the epithelial cell aggregates was obtained by weighing cut-out sections of the tracing. The area of cortex was expressed as a percentage of the area of entire thymus in the circle, and the area of epithelial cell aggregates was expressed as a percentage of the area of medulla.

The 64 sq. $\mathrm{mm}$. circle was scanned to make a direct count of the two types of Hassall's corpuscles and plasma cells. Hassall's corpuscles were expressed in terms of density, this being the number per square millimetre of medulla, and cystic Hassall's corpuscles as a percentage of all Hassall's corpuscles.

The control cases were grouped by stress involution, minimal and definite, and by age, the age groups being $<1$ year, 1-10, $11-20,21-40,41-60$, and greater than 60 years. Thus there were 12 control groups. For each control group, and for the
13 cases of systemic lupus erythematosus, the mean value and standard error were obtained for the various indices under consideration except for plasma cells; these were counted in 65 control stress-involuted thymuses and 11 thymuses from cases of systemic lupus erythematosus, cases with infection having been excluded (Goldstein, 1966). The mean age of the group with systemic lupus erythematosus was 27 years, and the values for this group were therefore compared with those of the group aged 21-40 years with stress involution. The statistical significance of differences in various comparisons was assessed by Student's $t$ test.

\section{Results}

The results for the control groups are shown in Table I. The results for the group with minimal stress showed that the percentage area of cortex was maximal in the $<1$ age group $(61 \pm 6 \%)$ and fell progressively with increasing age to $33 \pm 16 \%$ for the over-60 age group. Epithelial cell aggregates were absent in almost all age groups. The density of Hassall's corpuscles fell progressively with age without significant change in the percentage of cystic corpuscles. Sparse medullary germinal centres were seen in two cases.

The results for the stress-involuted thymuses were strikingly different, and, except for those aged 11-20, showed a progression of changes with age. Thus the percentage area of cortex was considerably reduced and fell with age from $26 \pm 13 \%$ to $0 \%$. Epithelial cell aggregates were present in all age groups, and mean values for their percentage area rose from $4 \pm 4 \%$ in the $<1$ age group to $17 \pm 4 \%$ for the over-60 age group, but the maximum value was $21 \pm 9 \%$ for the age group 11-20. All age groups showed a greater percentage of cystic Hassall's corpuscles, but no thymus contained a germinal centre. The 65 stress-involuted thymuses used for estimating plasma cell density were not grouped by age ; the value for the whole group was $5 \pm 2$ per sq. $\mathrm{mm}$.

The results for the 13 cases of systemic lupus erythematosus are shown in Table II. A thymic weight was obtained in five cases, including the three surgically resected thymuses. The weights, 5.0 to 9.6 g., were well below the normal range (Boyd, 1932) (Fig. 1). There was complete loss of cortex in all cases (Fig. 2). The medulla appeared "disorganized" and "collapsed," but the most striking change was prominent epithelial cell aggregates; their percentage area ranged from 13 to 70 , with a mean of $36 \pm 1$ for the whole group (Fig. 3). This mean figure was significantly greater than the mean percentage area for all control groups, including the group of stressed patients aged $21-40$ years $(\mathrm{P}<0.001)$. The density of Hassall's corpuscles was generally reduced (Fig. 4), but the significant change in comparison with the controls was a greatly increased percentage of cystic Hassall's corpuscles $(P<0.01)$ (Fig. 5). In two cases there were typical germinal centres in the medulla; these were numerous in one case (Mackay and de Gail, 1963 ;

TABLE I.-Results of Quantitative Histological Study of 198 Thymuses from Control Cases Grouped According to Age and the Expected Degree of Stress Involution (see text)

\begin{tabular}{|c|c|c|c|c|c|c|c|}
\hline $\begin{array}{l}\text { Age Range } \\
\text { (years) }\end{array}$ & No. of Cases & Terminal Illness & $\begin{array}{l}\text { Percentage Area } \\
\text { of Cortex } \\
\text { (\% of Thymus) }\end{array}$ & $\begin{array}{l}\text { Percentage Area } \\
\text { of Epithelial } \\
\text { Cell Aggregates* } \\
\text { (\% of Medulla) }\end{array}$ & $\begin{array}{c}\text { Density of Hassall's } \\
\text { Corpuscles* } \\
\text { (No./sq. mm. } \\
\text { Medulla) }\end{array}$ & $\begin{array}{l}\text { Percentage of Cystic } \\
\text { Hassall's Corpuscles* }\end{array}$ & $\begin{array}{l}\text { Germinal } \\
\text { Centrest }\end{array}$ \\
\hline & 12 & MS & $\begin{array}{l}61 \pm 6 \\
26 \pm 13\end{array}$ & $\stackrel{0}{4 \pm 4}$ & $\begin{array}{r}11.9 \pm 2.9 \\
21.9 \pm 4.6 \\
7.5+1.3\end{array}$ & $\begin{array}{l}17 \pm 7 \\
61 \pm 12 \\
34+13\end{array}$ & $\begin{array}{l}\mathbf{0} \\
\mathbf{0} \\
\mathbf{0}\end{array}$ \\
\hline $1-10$ & $\begin{array}{r}10 \\
4\end{array}$ & $\begin{array}{l}\text { MS } \\
\text { SI }\end{array}$ & $\begin{array}{l}49 \pm 8 \\
16 \pm 14\end{array}$ & $\begin{array}{c}0 \\
8 \pm 8\end{array}$ & $\begin{array}{l}7 \cdot 5 \pm 1 \cdot 3 \\
7 \cdot 2 \pm 3 \cdot 2\end{array}$ & $\begin{array}{l}34 \pm 13 \\
78 \pm 19\end{array}$ & $\begin{array}{l}0 \\
0\end{array}$ \\
\hline $11-20$ & $\begin{array}{r}10 \\
7\end{array}$ & $\begin{array}{l}\text { MS } \\
\text { SI }\end{array}$ & $\begin{array}{r}53 \pm 6 \\
4 \pm 4\end{array}$ & $\stackrel{0}{21 \pm 9}$ & $\begin{array}{l}5.9 \pm 0.8 \\
3.5 \pm 0.9\end{array}$ & $\begin{array}{l}37 \pm 8 \\
51 \pm 13\end{array}$ & $\begin{array}{l}1 \\
0\end{array}$ \\
\hline $21-40$ & $\begin{array}{l}20 \\
20\end{array}$ & $\begin{array}{l}\text { MS } \\
\text { SI }\end{array}$ & $\begin{array}{l}40 \pm 4 \\
10 \pm 5\end{array}$ & $\begin{array}{c}0 \\
8 \pm 3\end{array}$ & $\begin{array}{l}5.2 \pm 0.9 \\
2.8 \pm 0.6\end{array}$ & $\begin{array}{l}27 \pm 6 \\
57 \pm 8\end{array}$ & $\begin{array}{l}0 \\
0\end{array}$ \\
\hline $41-60$ & $\begin{array}{l}36 \\
39\end{array}$ & $\begin{array}{l}\text { MS } \\
\text { SI }\end{array}$ & $\begin{array}{r}26 \pm 3 \\
4 \pm 2\end{array}$ & $\begin{aligned} 1 \pm 1 \\
13 \pm 3\end{aligned}$ & $\begin{array}{l}2.6 \pm 0.4 \\
2.9 \pm 0.4\end{array}$ & $\begin{array}{l}29 \pm 5 \\
45 \pm 6\end{array}$ & $\begin{array}{l}1 \\
0\end{array}$ \\
\hline$>60+$ & $\begin{array}{r}6 \\
27\end{array}$ & $\begin{array}{l}\text { MS } \\
\text { SI }\end{array}$ & $33 \pm 16$ & $\begin{array}{c}0 \\
17 \pm 4\end{array}$ & $\begin{array}{l}2 \cdot 6 \pm 2 \cdot 4 \\
1 \cdot 3 \pm 0.4\end{array}$ & $\begin{array}{l}18 \pm 16 \\
28 \pm 8\end{array}$ & $\begin{array}{l}\mathbf{0} \\
\mathbf{0}\end{array}$ \\
\hline
\end{tabular}


Burnet and Mackay, 1965) and sparse in the other. Both were surgically resected thymuses, and neither patient had received treatment with corticosteroid drugs. The mean density of plasma cells in the thymus in systemic lupus erythematosus was significantly increased to $68 \pm 22$ per sq. $\mathrm{mm}$. $(P<0.05)$.

\section{Discussion}

The main question that arises from the present study concerns the specificity and significance of the various histological changes in the thymus in systemic lupus erythematosus, since

TABLE II.-Results of Quantitative Histological Study of the Thymuses in 13 Cases of Systemic Lupus Erythematosus. Means for these Cases are Contrasted with Means for Controls Aged 20-40 Years

\begin{tabular}{|c|c|c|c|c|c|c|c|c|c|c|}
\hline Case No.* & $\underset{\text { (years) }}{\text { Age }}$ & Duration of Illness & $\begin{array}{c}\text { Specific } \\
\text { Treatment }\end{array}$ & $\begin{array}{l}\text { Thymic } \\
\text { Weight } \\
\text { (g.) }\end{array}$ & $\begin{array}{l}\text { Area of } \\
\text { Cortex } \\
\text { (\% of } \\
\text { Thymus) }\end{array}$ & $\begin{array}{c}\text { Area of } \\
\text { Epithelial } \\
\text { Cell } \\
\text { Aggregates } \\
\text { (\% of } \\
\text { Medulla) }\end{array}$ & $\begin{array}{c}\text { Density of } \\
\text { Hassall's } \\
\text { Corpuscles } \\
\text { (No./sq. mm. } \\
\text { Medulla) }\end{array}$ & $\begin{array}{l}\text { Percentage } \\
\text { of Cystic } \\
\text { Hassall's } \\
\text { Corpuscles }\end{array}$ & $\begin{array}{c}\text { Density of } \\
\text { Plasma Cells } \\
\text { (No/sq. mm. } \\
\text { Thymus) }\end{array}$ & $\begin{array}{l}\text { Germinal } \\
\text { Centres }\end{array}$ \\
\hline $\begin{array}{r}1 \\
2 \\
3 \\
4 \\
5 \\
6 \\
7 \\
8 \\
9 \\
10 \\
11 \\
12 \\
13 \\
\end{array}$ & $\begin{array}{l}15 \\
15 \\
17 \\
19 \\
20 \\
21 \\
26 \\
28 \\
29 \\
31 \\
35 \\
49 \\
56\end{array}$ & $\begin{array}{l}9 \text { weeks } \\
1 \text { year } \\
2 \text { years } \\
1 \text { year } \\
18 \text { months } \\
4 \text { years } \\
4 \text { "’ } \\
3 \text { "' } \\
7 \text { year } \\
15 \text { years } \\
4 \text { months } \\
28 \text { years }\end{array}$ & $\begin{array}{l}\text { Nil } \\
\mathbf{P}, \mathbf{M} \\
\mathbf{P}, \mathbf{M} \\
\mathbf{P} \\
\mathbf{P} \\
\mathbf{N} \\
\mathbf{N} \text { il } \\
\mathbf{P} \\
\mathbf{P} \\
\mathbf{P} \\
\mathbf{P} \\
\text { Nil } \\
\text { ” } \\
\text { ", }\end{array}$ & $\begin{array}{c}7 \cdot 1 \\
\text { N.A. } \\
9 \cdot 6 \\
\text { N.A. } \\
5 \cdot 0 \\
\text { N.A. } \\
\text {.' } \\
\text { "’. } \\
8 \cdot 5 \\
\text { N.A. } \\
\text { 5.0 }\end{array}$ & $\begin{array}{l}0 \\
0 \\
0 \\
0 \\
0 \\
0 \\
0 \\
0 \\
0 \\
0 \\
0 \\
0 \\
0\end{array}$ & $\begin{array}{l}38 \\
27 \\
38 \\
24 \\
43 \\
13 \\
70 \\
26 \\
33 \\
26 \\
44 \\
54 \\
36\end{array}$ & $\begin{array}{l}9.7 \\
0.7 \\
5.0 \\
0.7 \\
0.7 \\
3.5 \\
5.6 \\
4.5 \\
4.2 \\
2.1 \\
1.8 \\
4.0 \\
0\end{array}$ & $\begin{array}{r}83 \\
100 \\
100 \\
100 \\
57 \\
86 \\
100 \\
100 \\
98 \\
86 \\
67 \\
85\end{array}$ & $\begin{array}{r}106 \\
29 \\
26 \\
29 \\
50 \\
303 \\
35 \\
22 \\
46 \\
42 \\
6 \\
133 \\
53\end{array}$ & $\begin{array}{l}+ \\
0 \\
0 \\
0 \\
0 \\
0 \\
0 \\
0 \\
0 \\
0 \\
0 \\
0 \\
+\end{array}$ \\
\hline \multirow{2}{*}{\multicolumn{2}{|c|}{ Mean \pm standard error }} & S.L.E. & & & 0 & $36 \pm 1$ & $3.3 \pm 0.7$ & $89 \pm 2$ & $68 \pm 22$ & $2 / 13$ cases $\ddagger$ \\
\hline & & $\begin{array}{l}\text { Controls aged } \\
20-40 \text { years }\end{array}$ & \multicolumn{2}{|c|}{$\begin{array}{l}\text { Stress involution } \\
\text { Minimal stress }\end{array}$} & $\begin{array}{l}10 \pm 5 \\
40 \pm 4\end{array}$ & $8 \pm 3$ & $\begin{array}{l}2.8 \pm 0.6 \\
5.2 \pm 0.9\end{array}$ & $\begin{array}{l}45 \pm 6 \\
29 \pm 5\end{array}$ & $5 \pm 2 t$ & $\begin{array}{lll}0 / 20 & & \ddagger \\
0 / 20 & & \ddagger\end{array}$ \\
\hline
\end{tabular}

P = Prednisolone. $M=$ Mercaptopurine. N.A. $=$ Not available. $+=$ Present. $0=$ Not present.

A All female. Cases 1,5 , and 13 thymectomy specimens; remainder necropsy.
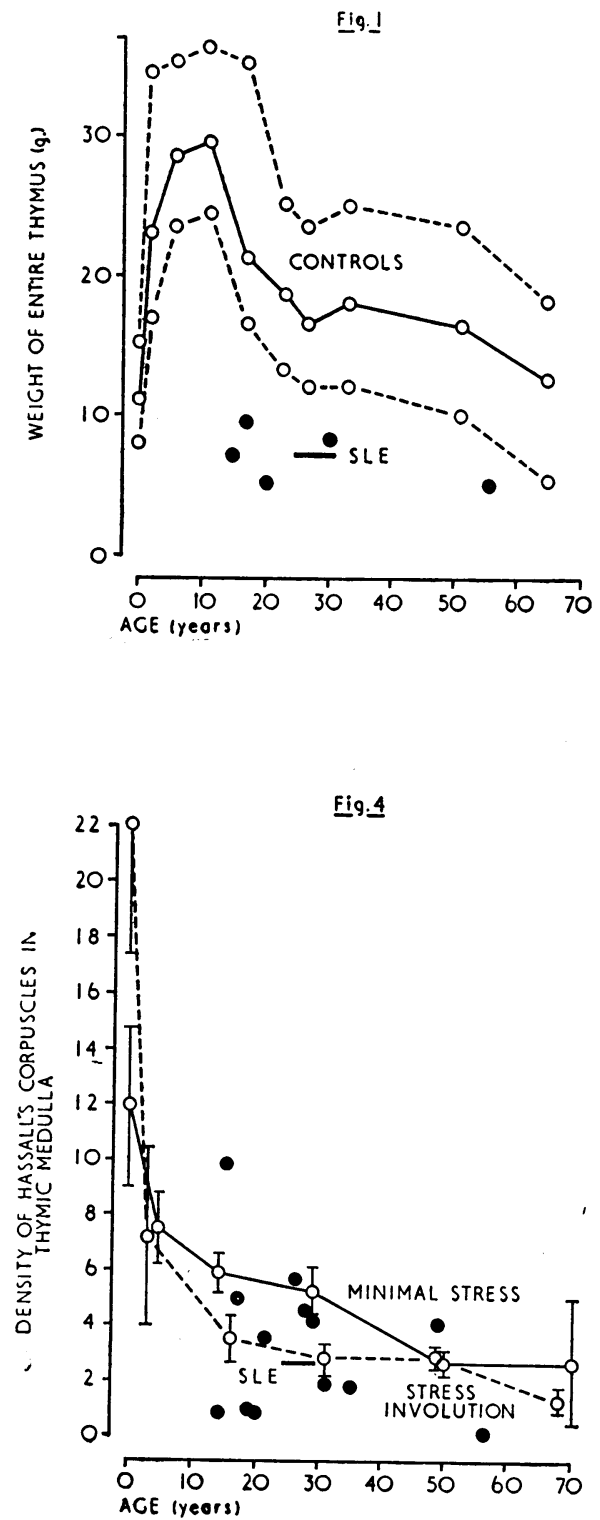
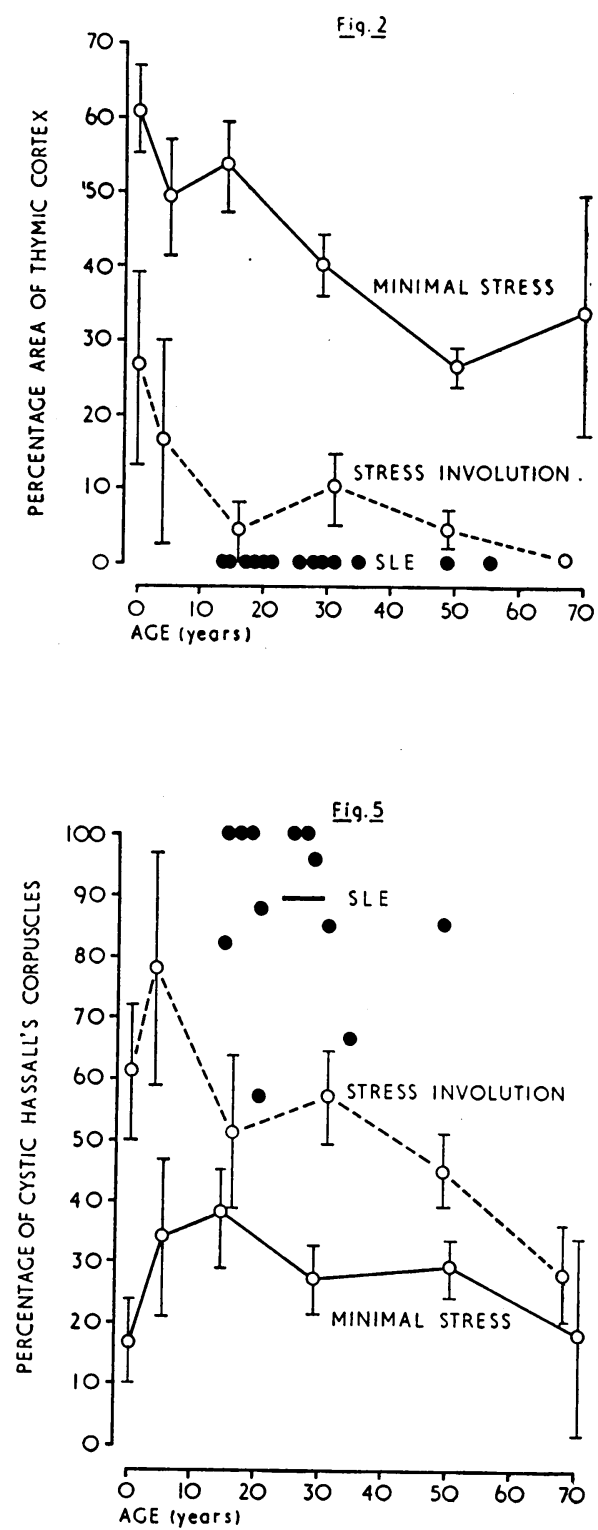

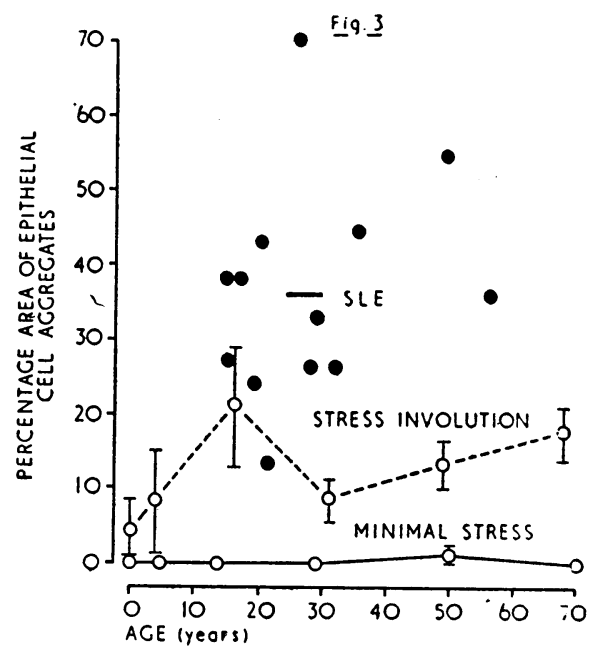

FIG. 1.- Thymic weight (solid circles) in five cases of systemic lupus erythematosus (horizontal bar represents mean weight) compared with thymic weights of controls takes from Boyd (1932), plotted as the means (solid line) and interquartile range (interrupted lines) for various age groups. The thymic weight was decreased age groups. The thymic weight was dect

Fig. 2. - Amount of thymic cortex expressed as a percentage area of entire thymus in a given area of a histological section. The means (open circles) and standard errors (vertical bars) are shown by age-grouping for subjects with minimal stress (solid line) and those expected to show stress involution (interrupted line) All patients with systemic lupus erythematosus (solid circles) had complete cortical atrophy.

FIG. 3.-Epithelial cell aggregates expressed as a percentage area of thymic medulla, the groups being as in Fig. 2. The proportion of epithelial cell aggregates in systemic lupus erythematosus (horizontal bar represents mean) was significantly

Fig. 4r--Density of Hassall's corpuscles in the thymus, the groups being as in Fig. 2. The density of Hassall's corpuscles decreased with age, but there were no significant differences be mean for the group with systemic lupus Fig. 5.-Percentage of cystic in the thymus, the groups being as in Fig. 2 . The percentage of cystic Hassall's corpuscles was increased in stress involution and significantly so again in patients with systemic lupus erythe- 
certain of these changes occurred to a lesser degree in stress involution. The stress-involuted thymuses in our study showed the well-known change of cortical atrophy (Hammar, 1921), cystic Hassall's corpuscles, which have been observed in the involuted thymuses of guinea-pigs given cortisone or $x$-irradiation (Blau, 1965), and an increased percentage area of epithelial cell aggregates, these also being regarded by Lattes (1962) as associated with stress. The nature of these epithelial aggregates remains uncertain. Their appearances may be due simply to loss of lymphocytes with condensation of reticuloepithelial cells, or they may represent hyperplasia of reticuloepithelial cells, perhaps as a reaction to stress. The fact that these epithelial aggregates are seen to some degree in stressed thymuses makes it unlikely that they have any unique relation to systemic lupus erythematosus.

The finding that certain of the thymic changes in svistemic lupus erythematosus are an exaggeration, albeit gross, of those present in stress involution is in keeping with the prolonged and often debilitating course of the disease, the long terminal stages, and intense treatment with "thymolytic" drugs such as corticosteroids and mercaptopurines. However, we would emphasize that our series contained three surgically resected thymuses, two of which were from patients who had not received "thymolytic" drugs, yet both showed changes as pronounced as others in the series. On the other hand, the greatly increased numbers of plasma cells in the thymus in systemic lupus erythematosus and the presence of germinal centres in the medulla in two of the cases could not be accounted for by stress involution, and point rather to an immune (probably autoimmune) reaction within the thymus (Goldstein, 1966).

C.un interpretation is that the thymus in systemic lupus erythematosus is a target organ. There is histological evidence of extreme stress involution and of an autoimmune reaction which could augment changes usually associated with stress involution.

\section{Summary}

Structural changes in the thymus were assessed by a quantitative method in 13 patients with systemic lupus erythematosus and in two groups of control cases representing minimal stress (94 cases) and stress involution (104 cases).

The changes of stress involution included reduction of cortex, epithelial cell aggregates in the medulla, and cystic Hassall's corpuscles. In systemic lupus erythematosus there was pronounced lymphocytic depletion resulting in complete cortical atrophy and disorganization of the medulla. A large proportion of the medulla (mean 36\%) was occupied by epithelial cell aggregates, and there was a high proportion (89\%) of cystic Hassall's corpuscles; moreover, there were greatly increased numbers of plasma cells, and germinal centres were present in two cases.

Our interpretation is that the thymus in systemic lupus erythematosus is a target organ. There is histological evidence of extreme stress involution and of an autoimmune reaction which could augment changes usually associated with stress involution.

We are grateful to Dr. J. D. Hicks, pathologist to the Royal Melbourne Hospital, Dr. J. McNamara, pathologist to the Coroner's Court, Melbourne, and Dr. A. Williams, pathologist to the Royal Children's Hospital, Melbourne, for enabling us to obtain thymuses for our control series. Dr. Grover M. Hutchins kindly referred three thymuses from patients with systemic lupus erythematosus (Cases 7, 8, and 9, Table II) from the Johns Hopkins Hospital, Baltimore. Mrs. Louise Stewart and Mr. A. Bargerbos provided excellent technical assistance.

\section{REFERENCES}

Blau, J. N. (1965). Nature (Lond.), 208, 564.

Boyd, E. (1932). Amer. F. Dis. Child., 43, 1162

Burnet, F. M. (1962). Aust. Ann. Med., 11, 79.

- and Mackay, I. R. (1965). F. Path. Bact., 89, 263.

Goldstein, G. (1966). Aust. F. exp. Biol. med. Sci., 44, 695.

- (1967). Clin. exp. Immunol., 2, 103.

- (19) Mckay. I. R. (1965). Aust. 7. exp. Biol. med. Sci., 43, 38

Ham and Mackay, 1.12 . Endocrinology, $5,543$.

Hammar, J. A. (1921). Endocrinology, (1964). Bull. fohns Hopk. Hosp. 115,355 .

$115,355$.
Lattes, R. (1962). Cancer (Philad.), 15, 1224.

Mackay, I. R., and de Gail, P. (1963). Lancet, 2, 667

- Masel, M., and Burnet, F. M. (1964). Aust. Ann. Med., 13, 5 - and Smalley, M. (1966). Clin. exp. Immunol., 1, 129.
Nineteen liver transplants have been performed in large white pigs (20-30 kilograms) under halothane anaesthesia via an endotracheal tube. Donor and recipient were littermates

* Department of Surgery, University of Cambridge. in some cases; in others there was no relationship. The surgical technique was similar to that of Moore et al. and of Starzl et al.; however, minor modifications of the shunting procedure and arterial anastomosis were incorporated in certain experiments. In the first 11 operations, during the interruption of flow through the portal vein and inferior vena cava, blood from these two systems was shunted via catheters in the splenic and left femoral veins respectively joined to a $T$ tube which connected to another catheter introduced into the left internal jugular vein. In the twelf th experiment two shunts were usedone from the splenic vein to the left jugular vein, the other from the right renal vein to the right jugular vein. The right kidney was removed. In the remaining seven operations catheters were inserted direct into the cut ends of the portal vein and inferior vena cava and connected respectively to the left and right jugular veins. In all cases the animals were heparinized while the shunts were open and the heparin was reversed with protamine at the end of the procedure. In the 